Siam Mapped 



\title{
Siam Mapped
}

\author{
A History of the \\ Geo-Body of a Nation
}

\author{
Thongchai Winichakul
}

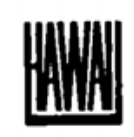

University of Hawai'i Press / Honolulu 
(c) 1994 University of Hawaii Press

All rights reserved

Printed in the United States of America

Paperback edition 1997

$\begin{array}{llllllllll}19 & 18 & 17 & 16 & 15 & 10 & 9 & 8 & 7 & 6\end{array}$

\section{Library of Congress Cataloging-in-Publication Data}

Thongchai Winichakul.

Siam mapped: a history of the geo-body of a nation / Thongchai Winichakul.

p. $\quad \mathrm{cm}$.

Includes bibliographical references and index.

ISBN 0-8248-1337-5

1. Thailand-Historical geography.

DS563.9.T47 1994
911.593-dc20 93-34494
CIP

ISBN 978-0-8248-1974-3 (pbk)

University of Hawai'i Press books are printed on acid-free paper and meet the guidelines for permanence and durability of the Council on Library Resources

Design by Kenneth Miyamoto 